\title{
Urban Farmers Willingness to Pay for Organic Fertilizer in District Mardan, Khyber Pakhtunkhwa, Pakistan
}

\section{Muhammad $^{1 *}$, Muhammad Suleman Bacha $^{2}$ and Syed Akhtar Ali Shah ${ }^{1}$}

${ }^{1}$ Department of Urban and Regional Planning, University of Peshawar, Khyber Pakbtunkhwa, Pakistan; ${ }^{2}$ Department of Environmental science, University of Peshawar, Khyber Pakhtunkhwa, Pakistan.

Abstract | The changing paradigm from a linear economy to a bio-based circular economy is key to sustainable urban waste management planning. The goal is to reduce the environmental damages, enhance food supply, increase employment opportunities and broke the vicious circle of poverty. This study performs a focalized analysis and investigates the influencing factors of urban farmers' Willingness to Pay (WTP) for organic fertilizer in District Mardan, Pakistan. The Contingent Valuation Method (CVM) was used and data were randomly collected from 384 heads of the household of urban farmers. Data was set in SPSS software version 22.0 and analyzed using descriptive statistics and Logit Model. The study revealed that a major proportion $(62.5 \%)$ of solid waste is generated from domestic sources followed by commercial (26.9\%), institutions $(5.8 \%)$ and industrial $(2.9 \%)$ sources. While the majority of respondents $(81 \%)$ were concerned about the unsafe disposal of solid waste and are willing to pay for organic fertilizer alternative to chemical fertilizer for urban agriculture. We also found that socio-economic variables namely education, monthly expenses, and agriculture farm size positively affect farmers' WTP for organic fertilizer. Conversely, households' size and land tenure of the farmer has a negative influence on farmers'WTP. An Integrated Resource Recovery Centre (IRRC) is needed for green waste management to change the current paradigm by transforming the waste into a valuable resource. The application of WTP can be an effective tool for urban planners and policymakers to incorporate the views of urban dwellers for sustainable SWM, food self-sufficiency and financial autonomy of the public utility company.

Received | January 16, 2020; Accepted | March 18, 2020; Published | April 20, 2020

*Correspondence | Muhammad, Department of Urban and Regional Planning, University of Peshawar, Khyber Pakhtunkhwa, Pakistan; Email: ecoplanner79@gmail.com

Citation | Muhammad, M.S. Bacha and S.A.A. Shah. 2020. Urban farmers willingness to pay for organic fertilizer in District Mardan, Khyber Pakhtunkhwa, Pakistan. Sarbad Journal of Agriculture, 36(2): 419-426.

DOI | http://dx.doi.org/10.17582/journal.sja/2020/36.2.419.426

Keywords | Contingent valuation method, Logit model, Organic fertilizer, Recycling, Willing to pay

\section{Introduction}

$\mathrm{U}$ rbanization is a universal phenomenon, and its varying pace in different countries increase demand for public services and food security (Cofie et al., 2006). In developing countries, the pull and push factors are not only annexing the agricultural land but also increasing the volume of urban waste (Mougeot, 2000). In these countries, the issue of sustainable solid waste management (SWM) presents a challenge as the generation is at alarming rate and the composition is more complex (Chew et al., 2019). Moreover, the lack of urban planning, inappropriate legal framework, weak governance, widespread poverty, limited or inadequate financial resources further exacerbate the waste management problems (Armar-Klemesu, 2000; Awunyo-Vitor et al., 2013). As 'waste' is an unwanted or unusable material and 
haven't a value for the first user (Cofie and Dreschel, 2006). Most of the solid waste is disposed linearly under the take, make, dispose principle and are directly dumped into landfill without productive use (Ludwig et al., 2012). The sustainable management of SWM through 'circular economy' is complementary for green economy and financial autonomy of the cities (Case et al., 2017). It also improves the waste nutrient content which is rich in Nitrogen, phosphorous, and Potassium (Lee-Smith, 2010).

However, municipalities have inadequate technical, financial, and institutional capacities to collect, transport, recycle and reuse for agriculture and other purposes (Drechsel and Kunze, 2001). An integrated green economy approach of $3 \mathrm{Rs}$ (reuse, recycle and recover) can not only help in sustainability in waste management but also ensure fiscal autonomy and food security of the urban dwellers (Okot-Okumu, and Nyenje, 2011; Tukahirwa, 2011). In recent past the use of compost waste for urban agriculture like backyard garden, street landscaping, tactical gardens, rooftop garden, green house, green wall and vertical farming has been increasingly recognized in many developing countries (Okon et al., 2018; Shee et al., 2020). The use of organic fertilizer increases soil fertility (Ye et al., 2020). Further, it will not only mitigate the food supply disruption, improve the esthetics of the local environment but will make the cities as an engine of economic growth as well (Rind, 2005; Zezza and Tasciotti, 2010). In Pakistan solid waste mismanagement is major threat to public health, environment, aesthetics and economics. The average solid waste generation in the country is 0.283 to $0.612 \mathrm{~kg} /$ capita /day with $2.4 \%$ growth rate per year (Khan et al., 2012). The major cities are the main waste generator and increase has been recorded with population growth (Figure 1). The waste is disposed unsustainably which pose serious health concerns through clogging of drains, ponds of stagnant water and making of safe resorts for breeding of mosquitos (Mahar et al., 2007).

In Mardan, most of the households linearly dump waste near their houses, in rivers, into sewage, drains and at other illegal sites without sustainable SWM practices. An engineering approach to solid waste collection and reuse as an organic fertilizer by city dwellers will make an opportunity both financially and environmentally for the city authority. Further, it will maintain the food supply chain of the city and will create opportunity for the urban poor. This study is an attempt to render insight of the urban farmers' perceptions and analyze their enthusiasm of willingness to pay (WTP) using Contingent Valuation (CV) survey method for adaptation of recycling compost waste (organic fertilizers). This information is a feasibility study for sustainable urban planning and springboard for upcoming mega projects e.g. Integrated Resource Recovery Centre (IRRC). In line of above background, the focus of this research is as under:

1. To assess the composition of SWM, public health and environmental concerns in urban Mardan.

2. To analyze urban farmer WTP and their determinants for organic fertilizer for agriculture purpose.

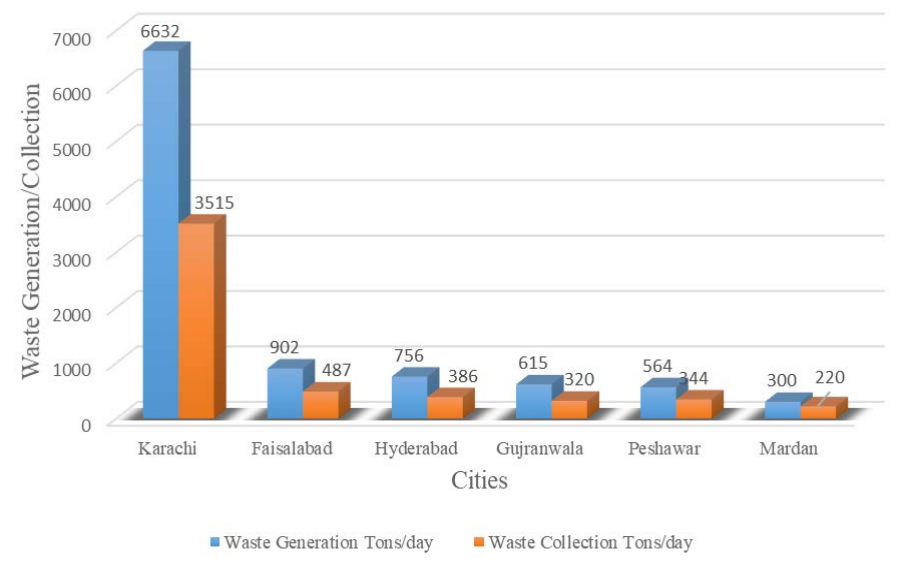

Figure 1: Solid waste generation and collection in major cities of Pakistan. Source: Mubammad et al., 2017

\section{Materials and Methods}

\section{Study area}

Mardan ( $71^{\circ} 48^{\prime}$ to $72^{\circ} 52^{\prime} \mathrm{E}$ and $34^{\circ} 05^{\prime}$ to $\left.34^{\circ} 32^{\prime} \mathrm{N}\right)$ (Khan et al., 2012) is a second major city of Khyber Pakhtunkhwa province, bounded by Buner and Swabi on East, Malakand on North, Charsadda and Malakand on west and Nowshera on south. The total population of District Mardan consist of 2,373,061 persons of which $18.5 \%$ lives in the urban area (GoP, 2107). The district covers 45 union councils and the study is confined to14 urban union councils (Figure 2).

The people are keen to adopt agriculture practices because of fertile land and forefather profession. However, as a second major city of Khyber Pakhtunkhwa, and rapid urbanization the city builtup area has been more than doubled and spur from $30 \%$ in 1990 to $64 \%$ in 2010 . Consequently, the agriculture land shrunk from 1,339 ha to 1,109 ha 
(Yar et al., 2016). Most of the urban farmer owns small plots in their backyards as well as vacant spaces between the dwellings. Most of the urban farmers grow vegetables, fruits and urban forestry. The use of organic fertilizer is not only prerequisite for intensive agriculture but also make the city aesthetic use of these small farms.

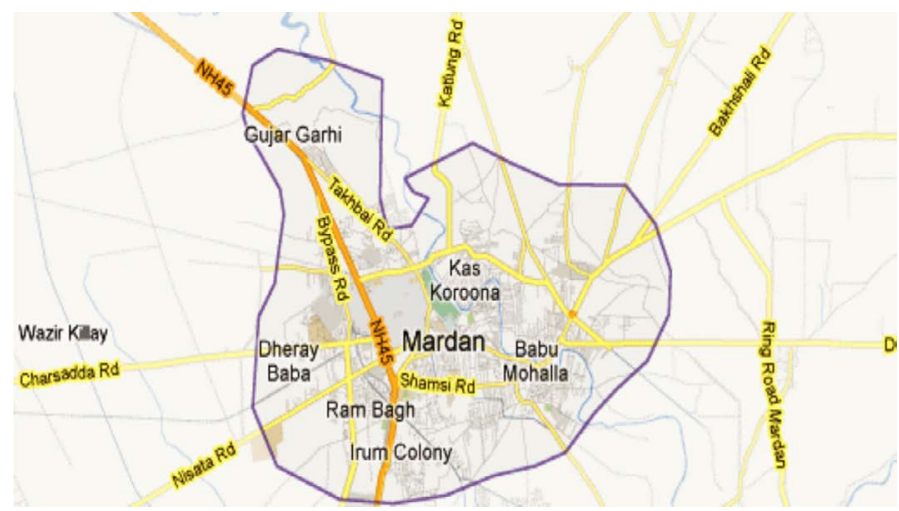

Figure 2: Map of Mardan, Pakistan.

\section{Sampling, survey design and data collection}

This study was conducted in January 2019 covering 14 urban union councils of district Mardan. Contingent Valuation (CV) survey method was used and data was collected from elite member of urban farmer. The sample size $(\mathrm{n}=384)$ was calculated using Equation 1:

$$
\mathrm{n}=\frac{\frac{Z^{2} \cdot p(1-p)}{e^{2}}}{1+\left(\frac{Z^{2} \cdot p(1-p)}{e^{2} N}\right)}
$$

\section{Where;}

$\mathrm{n}=$ Sample Size (SS); $\mathrm{Z}=\mathrm{Z}$-tabulated value is 1.96 (95\% confidence level and 5\% confidence interval); $\mathrm{e}=$ Sampling or margin of error at $5 \% ; \mathrm{p}=$ maximum variability of the population at $50 \%$. i.e. $(0.5) ; \mathrm{N}=$ Total population.

As focus of the study was farmers' WTP for organic fertilizer use in urban farming, a list of urban farmers in each union council was compiled with the help of water and sanitation service company (WSSC) and Agriculture Department Mardan. Later on, Sample size was proportionally allocated to each union council. A formal training/workshop was arranged before conducting the survey to train the respondents with the process and prepare them how to answer the asked questions. Consent was taken from each respondent before proceeding with the interview. A $100 \%$ positive rate was achieved out of 384 respondents.
Analytical procedure and model specification

Data was processed using SPSS (Statistical Package for the Social Sciences) and analyzed for descriptive statistics and Logit Model. The socio-economic characteristics of the respondents was assessed using descriptive statistics. For estimating urban farmer's willingness to pay for recycled waste, previous literature advocates numerous survey methods like Revealed Preference Method, Hedonic Travel Cost Approach, and Contingent Valuation Method. The present study quantifying farmer's WTP through hypothetical market, so Contingent Valuation Survey Method is appropriate method as suggested by (Mitchell and Carson, 1989; Alberini and Cooper, 2000; Muhammad et al., 2020).

For evaluating the determinants of farmer's WTP, literature suggests various models such as Logit Model, Tobit Models, Ordinary Least Square, and Symmetrically Trimmed Least Squares (Whitehead, 2006). Since the dependent variable are dichotomous (Yes, No) in nature, so Logit Model was used in the line of (Arene and Mbata, 2008; Bhattarai et al., 2017; Okon et al., 2108; Dika et al., 2019).

This Logit Model estimates the 'Yes' 'No' probability of farmer's WTP and is given by:

$$
\text { Probibility (event) }=\frac{1}{e^{-z}}
$$

Where;

$Z$ denotes the variables like $X_{1}, X_{2} \ldots \ldots . . . X n$

$$
\text { Probibility (event) }=\frac{1}{e^{-(\beta 0+\beta i X i)}}
$$

Taking the Log of above equation to determine the chances in favor of WTP as:

Ln (chance of an occurrence/ 1 - chance of an occurrence) $=Z$

In this model the ' $Z$ ' was constructed as:

$$
Z=\beta_{0}+\beta_{I} M E+\beta_{2} E d u+\beta_{3} H H s+\beta_{4} F S+\beta_{5} L T_{+} \varepsilon i \quad \ldots \text { (2) }
$$

In the above model, the regressand (WTP) is dichotomous taking value ' 1 ' if the farmer is willing to pay for compost and ' 0 ' otherwise. The description of each variable is given in Table 1. 
Table 1: Descriptive statistics of the variables in the model.

\begin{tabular}{|c|c|c|c|c|c|}
\hline Variables & Definition of variables & Minimum & Maximum & Mean & Std. Deviation \\
\hline $\mathrm{ME}$ & Monthly Expenditure (PKR) & 18000 & 145000 & 59010 & 25718.5 \\
\hline Edu & $\begin{array}{l}\text { Education ( } 0=\text { Illiterate, } 1=\text { Middle, } 2=\text { Secondary, } 3=\text { Higher Sec- } \\
\text { ondary, } 4=\text { Bachelor, } 5=\text { Master, } 6=\text { Higher level })\end{array}$ & 0 & 6 & 3.0 & 4.24 \\
\hline $\mathrm{HHs}$ & Size of Household (In Numbers) & 2 & 30 & 6.41 & 3.699 \\
\hline LT & land tenure $(0,1)$ & 0 & 1 & 0.797 & 0.403 \\
\hline FS & Farm Size (Kanal) & 0.15 & 3 & 0.839 & 0.5244 \\
\hline WTP & Willingness to Pay $(0,1)$ & 0 & 1 & 0.81 & 0.71 \\
\hline$\varepsilon \mathrm{i}$ & The effect of unmeasured variable in the model & & & & \\
\hline
\end{tabular}

Source: Field survey, 2019.

\section{Results and Discussion}

\section{Waste management in Mardan}

SWM has traditionally been dominated by the Government with agencies such as Tehsil Municipal Administration and Municipal Authorities providing Water, Sanitation and Hygiene (WASH) services. These agencies and city planner traditionally practices the SWM and have poor services. The pressing issues were attributed and compounded by centralized governance framework; lack of technical and professional skills; lack of political will; lack of proper planning; rampant corruption; prevalence of ghost employees; lack of across the board accountability and non-availability of specialized equipment/machinery, resulting in accumulation of solid waste within the posing serious threat to public health and pollution. The lack of any significant revenue stream means that agencies are entirely dependent upon Government grants which can be inadequate and untimely. Taking stock of the situation, the Khyber Pakhtunkhwa switched over to the corporate governance and established Water and Sanitation Service Company Mardan (WSSM) registered with the Security Exchange Commission of Pakistan under clause '42' of the companies' ordinance to address the provision of better municipal services in urban Mardan.

In Mardan most of the collected solid waste are linearly disposed in the form of take-make-consumethrow away pattern as given in Figure 3 . The city generates 300 ton/day of solid waste and 53\% comprises biodegradable including food, paperboard, leaves, grass, straw, wood, animals dung, sludge etc. only 65-70 tons of the waste generated is transported to landfill site daily and the remaining are not properly managed under the circular green economy concept, and frequently observed in open spaces, vacant plots and street/road corners and have bad smell and polluting the environment (Muhammad et al., 2017).

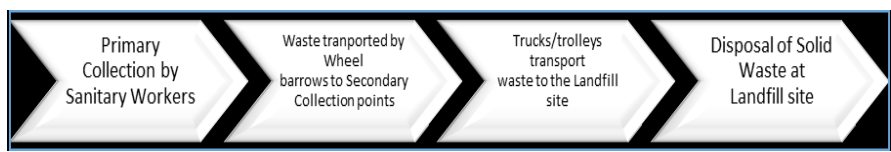

Figure 3: Linear waste collection cycle in urban Mardan.

There is an urgent need to introduce the paradigm shift in the policy direction, from linear to circular economy to transform this problem into an opportunity. The concept of circular economy (see Figure 4) is not just reduce the systemic harm engendered by a linear economy but also make the cities into engines of economic growth and creates a positive reinforcing development cycle.

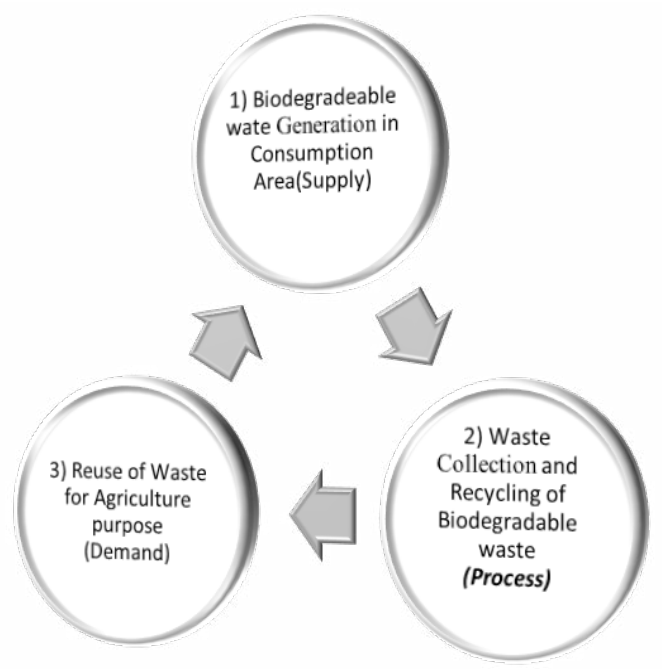

Figure 4: Bio-based circular economy loop.

It can be an important leverage to achieve key policymaker objectives such as food self-sufficiency, financial autonomy, creating jobs, and reducing environmental impact. 
Model variables

Table 1 gives detail of variables used in the model. Most of the interviewers were married, working age and hence no dependency. The average household size reported was 6.4 persons. Similarly, education of the respondents varied from illiterate to higher degree, however majority of respondents were matriculate and those having no formal Education. It was observed that interviewers do not divulge their real income due to many reasons. Therefore, questions were asked regarding their expenditure on various commodities and were used as an alternative for their monthly budget. Dualism were seen in the income of the urban farmers' and fluctuation from low to high income. According to the Economic theory purchasing power depends on the economic status of the consumers, means richer farmers induce to invest more as compared to their counterpart poor on purchasing compost for agriculture (Flores and Carson, 1997). The farm size of the respondents varied from 0.15 to 3 kanals, depending on the economic status of the respondent. Majority of the respondents own the land and almost all of them have uneconomic land holding in the form of empty plots, backyards etc.

\section{Characterization of solid waste}

The large burgeon of urbanization has overwhelmed the capacity municipal authorities to provide even basic services. Globally 1.3 billion metric tons of Municipal solid waste are generated annually and have positive relation between Gross Domestic Product and its volume (Kawai and Tasaki, 2016; Elagroudy et al., 2016). The city of Mardan generates average 300 Ton/Day and only 220 Ton/Day are collected and disposed of at dumping sites, and the remaining leachate from solid waste and wastewater a threat to the quality of water, city environment aesthetically unpleasant and public health (Muhammad et al., 2017). Figure 5 gives details of the various sources of city-wide waste generation. Domestic source (62.5\%) is the major contributor followed by commercial industrial and institution. The domestic solid waste constitutes organic biodegradable waste (53\%), inorganic or non-biodegradable waste $(38 \%)$ and non-putrescible are (10\%) (Muhammad et al., 2017).

The overall condition of soil in the Mardan is good and has a normal $\mathrm{pH}$. The organic matter in the soil is also rich and compost can improve the condition of present soil even more for increased crops production (Sarwar et al., 2002). Presently urban farmers in
Mardan practices chemical fertilizers, which are too expensive and not affordable for all of them. The domestic biodegradable waste can be converted to useful form of Fertilizer through proper compost mechanism like Integrated Resource Recovery Centre (IRRC) and the paradigm can be changed from threat to opportunity e.g. the waste can be used as a resource from which money can be used.

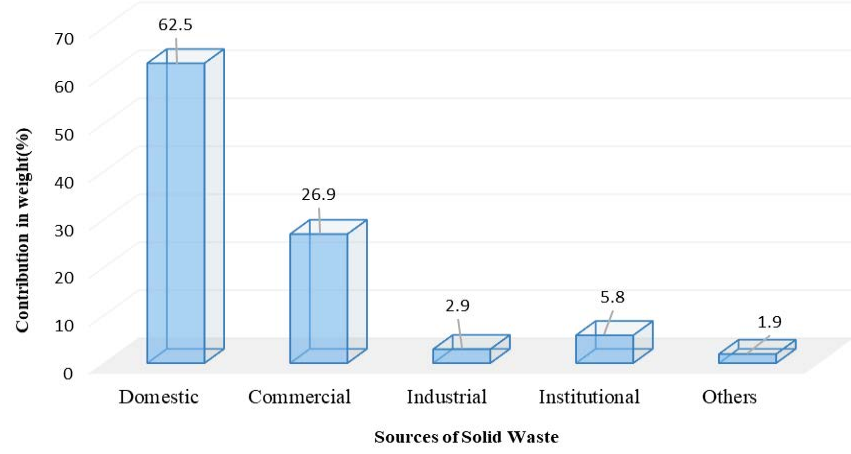

Figure 5: Solid waste generation in Urban Mardan.

Source: Water and sanitation services Mardan.

\section{Respondents' concerns regarding mismanagement of SWM}

SWM is one the crucial problems faced by city planners and policy makers in the least developed countries (Asomani-Boateng and Haight, 1999). The environment-poverty nexus is altogether ignored as the old traditional practices of "dumped, buried, thrown" in vacant plots still prevail (Hetzler, 2012).

Figure 6 shows the respondents concerns about the mismanagement of solid waste and ultimate human health hazards in the study area. It is evident from the results that majority of the respondent are worried about the diseases caused by flies and mosquitoes, clogging of drains and most importantly illegal dumping in water bodies. $78.8 \%$ showed concern about the reduction of natural resources and $78.8 \%$ presence of wastes in their neighborhoods.

Majority of urban farmers (81\%) have a positive attitude towards improvement and are willing to pay for organic fertilizer for agriculture purpose. For mitigating the human health and environmental risk, the reuse of compost waste to promote the organic farming is more compatible with the conservation of resources, ecology, health and economic policies in the area.

\section{Analysis of logit model}

The demand and WTP of urban farmer for organic June 2020 | Volume 36 | Issue 2 | Page 423 
fertilizer was conducted and analyzed through Logistic Regression Model given in Equation 2. Field survey revealed that $81 \%$ of farmer are WTP and use organic compost as a substitute of chemical fertilizers until or unless is close substitute and cost effective.

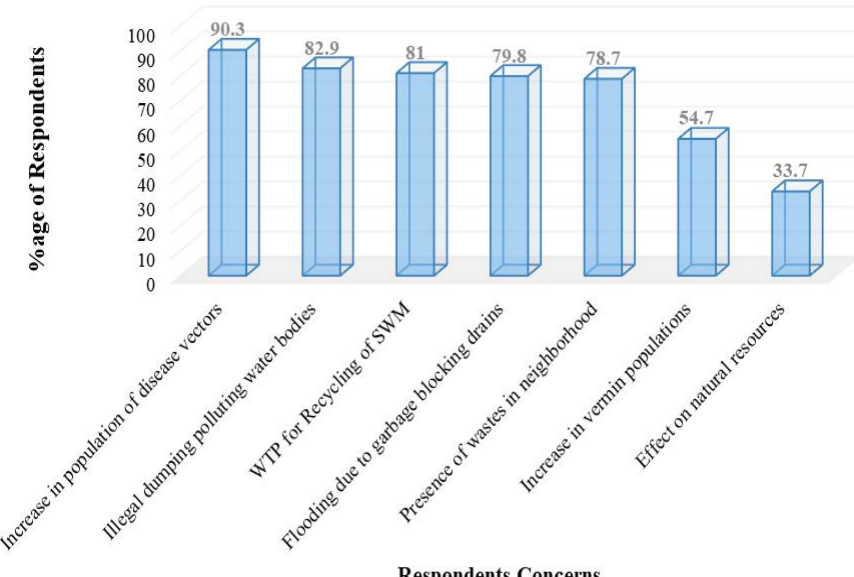

Figure 6: Respondents concern regarding mismanagement of SWM. Source: Field survey: 2019.

Table 2 presents importance of each variable in the Model. The odds ratio values corresponding to each variable indicates the variable's contribution to the odds in favor of WTP for reuse of composted waste as a fertilizer in urban agriculture. Analysis of the results show that only three factors are dominant in determining the households WTP for reuse (in the form of compost) of municipal waste for urban agriculture purpose. These variables are 'ME'Edu' $\mathrm{FS}$ ' and have loading greater than $50 \%$ and were selected as defining variables.

Table 2: Result of logistic regression model of farmer's willingness to pay for recycling of urban waste.

\begin{tabular}{llll}
$\begin{array}{l}\text { Inde- } \\
\text { pendent } \\
\text { variable }\end{array}$ & \multicolumn{2}{l}{$\begin{array}{l}\text { Dependent Variable: WTP for Recycling of } \\
\text { urban waste (Dichotomous) }\end{array}$} \\
Estimated coefficients & Odds ratio & Probability (\%) \\
ME & $2.979^{* * *}(0.387)$ & 19.59 & 95.1 \\
Edu & $1.409^{* * *}(0.1960)$ & 4.09 & 80.3 \\
HHs & $-0.037(0.620)$ & 0.96 & 48.9 \\
FS & $0.279^{* *}(0.152)$ & 1.32 & 56.9 \\
LT & $-0.436(0.490)$ & .642 & 39.1 \\
Constant & $-34.344^{* * *}(4.403)$ & .000 & --
\end{tabular}

Total no of survey respondents $(\mathrm{N})=384$; Value of Chi square $\left(\chi^{2}=252.897 ;\right.$ Pseudo $R^{2}=0.601$

In parenthesis Standard Error value are given; Above standard error value shows coefficient of variables $(\beta) ;{ }^{* * *}$ a value significant at $1 \%$; **a value significant at $5 \% ;{ }^{*}$ a value significant at $10 \%$

Source: Results of the logit model from the field data.
'ME', are statistically significant in the model at $\mathrm{P}$ $<0.05$ and $\mathrm{P}<0.01$. The odd-ratios column shows that 1 unit increase in ' $\mathrm{ME}$ ' as proxy of income leads to approximately 20 time increase in the farmer's WTP for reuse of recycle urban waste. This means that changes the ' $\mathrm{ME}$ ' by one unit have chances of $95 \%$ chance to pay for recycle for biodegradable urban waste. The positive relation between farmer income and urban farmer WTP for recycle waste are also confirmed by (Arene and Mbata, 2008). Further economic theory also suggests that income as a key for demand shifter and directly related to WTP of the respondents (Horowitz and McConnell, 2003). 'Edu' are also statistically significant at $\mathrm{P}<0.01$. The oddratio value of farmer's education is high, means that educated respondents are more conscious regarding the ambient environment and food shortages due urbanization and urban land annexation.

Farm Size 'FS' have also had a positive and dominant role in farmers WTP for reuse of urban waste. It is clear from Table 2 that 'LT' value is significant at $\mathrm{P}<0.05$ and odds ratio value greater than ' 1 ' means that increase in 'FS' by one rank have the chance of $57 \%$ to make changes of farmers WTP for reuse of recycle urban waste as a fertilizer.

Further the coefficient of 'HHs' and have negative signs, means that besides household size other factors also determine farmers WTP and were also confirmed by (Okon et al., 2018). Similarly, the coefficient values of 'LT' show negative sign means that land tenure doesn't have role in urban farmers WTP for compost as a green manure. As a conclusion for making the city, economically vibrant and environmentally feasible for the urban dwellers the planner and policy makers must have to take into consideration the determinants of WTP and ensure public participation during planning phase for sustainable SWM in the area.

\section{Conclusions and Recommendations}

The reuse of compost as a fertilizer by urban farmers is an opportunity for addressing waste disposal problem in cities of Pakistan. This circular economy approach can not only overcome the problems of health but also the institutional and official attitudes. These can be addressed by involving and educating the relevant actors and initiating institutional changes. The concept of Integrated Resource Recovery Centers (IRRC) is not new to Pakistan, but requires fundamental 
changes in planning urban areas, as well as a change in the attitude of city governments, decision makers, and urban planners. It is recommended for the city planner that the present linear approach of solid waste management planning needs to be replaced by circular approach and participatory approach to sustainably manage the solid waste problem in the area. This approach will promote and encourage the organic farming in the city and will make the city economically vibrant and environmentally more aesthetic.

\section{Novelty Statement}

The present study is a comprehensive assessment and willingness to pay of urban farmers for using compost in agriculture practices in District Mardan of Pakistan. It will be an addition to literature in the capacity of various factors contributing to recycling of total waste produced an underdeveloped economy.

\section{Author's Contributions}

Muhammad designed the research plan and data analysis for this study and prepared the first draft of the manuscript. Muhammad Suleman Bacha assisted in results interpretation and discussion part. Syed Akhtar Ali shah performed tabulation and reviewed the manuscript and helped in overall improvement of the final draft of the manuscript.

\section{Conflict of interest}

The authors have declared no conflict of interest.

\section{References}

Alberini, A. and J. Cooper. 2000. Applications of the contingent valuation method in developing countries: A survey. Food Agric. Org. 146. http://www.fao.org/3/X8955E/X8955E00. htm (Retrieved March 24, 2020 )

Arene, C.J. and G.I. Mbata. 2008. Determinants of profitability and willingness to pay for metropolitan waste-use in urban agriculture of the federal capital territory, Abuja, Nigeria. Agro-Sci., 7(1): 41-46. https://doi. org/10.4314/as.v7i1.1582

Armar-Klemesu, M., 2000. Urban agriculture and food security, nutrition and health. Growing cities, growing food. Urban Agric. Policy Agenda. pp. 99-118.
Asomani-Boateng, R. and M.Haight.1999.Reusing organic solid waste in urban farming in African cities: A challenge for urban planners. Third World Plann. Rev. 21(4): 411. https://doi. org/10.3828/twpr.21.4.5537184137847u14

Awunyo-Vitor, D., S. Ishak and G.S. Jasaw. 2013. Urban households' willingness to pay for improved solid waste disposal services in Kumasi Metropolis, Ghana. Urban Stud. Res., 2013. https://doi.org/10.1155/2013/659425

Bhattarai, K., B. Pathak and K.C. Binod. 2017. An analysis of households' demand for improved solid waste management in Birendranagar municipality, Nepal. Int. J. Energy Econ. Policy. 7(4): 83-89.

Case, S.D.C., M. Oelofse., Y.Hou., O. Oenema and L.S. Jensen. 2017. Farmer perceptions and use of organic waste products as fertilisers, A survey study of potential benefits and barriers. Agric. Syst. 151: 84-95. https://doi.org/10.1016/j. agsy.2016.11.012

Chew, K.W., S.R. Chia., H.W.Yen., S. Nomanbhay., Y.C. Ho. and P.L. Show. 2019. Transformation of biomass waste into sustainable organic fertilizers. Sustainability. 11(8): 2266. https:// doi.org/10.3390/su11082266

Cofie, O., A.A. Bradford and P. Dreschel. 2006. Recycling of urban organic waste for urban agriculture. Cities farming for the future. Urban Agric. Green Prod. Cities. pp. 207-229.

Dika, G., A. Nemie and E. Birhane. 2019. Household's willingness to pay for improved solid waste management in Gulelle Sub City, Addis Ababa.

Drechsel, P. and D. Kunze. 2001. Waste composting for urban and peri-urban agriculture: Closing the rural-urban nutrient cycle in sub-Saharan Africa. CABI. https://doi. org $/ 10.1079 / 9780851995489.0000$

Elagroudy, S., M.A. Warith and M. El-Zayat. 2016. Municipal solid waste management and green economy. Glob. Young Acad. pp. 10-15.

Flores, N.E. and R.T. Carson. 1997. The relationship between the income elasticities of demand and willingness to pay. J. Environ. Econ. Manage. 33(3): 287-295. https://doi. org/10.1006/jeem.1997.0998

GoP. 2017. District census report of Peshawar. Population census organization statistic division, GoP.

Hetzler, E., 2012. The interconnection of 
environment and poverty: Prospects for sustainable development.

Horowitz, J.K. and K.E. McConnell. 2003. Willingness to accept, willingness to pay and the income effect. J. Econ. Behav. Organ. 51(4): 537-545. https://doi.org/10.1016/S01672681(02)00216-0

Kawai, K. and T. Tasaki. 2016. Revisiting estimates of municipal solid waste generation per capita and their reliability. J. Mater. Cycles Waste Manage., 18(1): 1-3. https://doi.org/10.1007/ s10163-015-0355-1

Khan, A.A., Z. Ahmed and M.A. Siddiqui. 2012. Issues with solid waste management in South Asian countries: A situational analysis of Pakistan. J. Environ. Occup. Sci. 1(2): 129-131. https://doi.org/10.5455/jeos.20120731084356

Khan, N., S.T. Hussain, A. Saboor, N. Jamila, S. Ahmed, R. Ullah and K.S. Kim. 2012. Bacteriological investigation of ground water sources in selected urban areas of district Mardan, Khyber Pakhtunkhwa, Pakistan. Afr. J. Biotechnol., 11(51): 11236-11241. https://doi. org/10.5897/AJB12.914

Lee-Smith, D., 2010. Cities feeding people: An update on urban agriculture in equatorial Africa. Environ. Urbanization. 22(2): 483-499. https://doi.org/10.1177/0956247810377383

Ludwig, C., S. Hellweg and S. Stucki. 2012. Municipal solid waste management: strategies and technologies for sustainable solutions. Springer Sci. Bus. Media.

Mahar, A., R.N. Malik., A. Qadir., T. Ahmed., Z. Khan and M.A. Khan. 2007. Review and analysis of current solid waste management situation in urban areas of Pakistan. Proc. Int. Conf. Sustainable Solid Waste Manage. 8: 36.

Mitchell, R.C. and R.T. Carson. 1989. Using surveys to value public goods: the contingent valuation method. Resour. Future.

Mougeot, L.J., 2000. Urban agriculture: Definition, presence, potentials and risks, and policy challenges. Cities Feed. People Ser. Rep. pp. 31.

Muhammad, U. Hayat., E.N.G. Khan and S.A.A. Shah. 2017. The Current Practices, Concerns and Willingness to Pay for Domestic Solid Waste Management Services in Urban Areas of Mardan, Pakistan. J. Appl. Environ. Biol. Sci. 7(12): 306-315.

Muhammad, U. Hayat, S.A.A. Shah, M.S. Bacha,
T. Shah and H. Bilal. 2020. Willingness to Pay for Quality Drinking Water Services in Urban Centre: A Case Study of Peshawar, Pakistan. Fresenius Environ. Bull. 29(3): 14651473.

Okon, U.E., K.K. Nkeme, U.A. Essien, E.U. Solomon and U.U. Solomon. 2018. Urban Farmers' Willingness to Pay and Utilize Urban Waste for Agriculture in Akwa Ibom State, Nigeria. Am. J. Environ. Prot., 6(2): 50-53.

Okot-Okumu, J. and R. Nyenje. 2011. Municipal solid waste management under decentralization in Uganda. Habitat Int. 35(4): 537-543. https:// doi.org/10.1016/j.habitatint.2011.03.003

Rind, J.A., 2005. Need and potential of urban agriculture potential exists in big cities.

Sarwar, T., A. Javed and M. Tariq. 2002. Impact of tile drainage on soil and water quality in Mardan SCARP area. Asian J. Plant Sci. 1(4): 484-488. https://doi.org/10.3923/ajps.2002.484.488

Shee, A., C. Azzarri and B. Haile. 2020. Farmers' willingness to pay for improved agricultural technologies: Evidence from a field experiment in Tanzania. Sustainability, 12(1): 216. https:// doi.org/10.3390/su12010216

Tukahirwa,J.,2011. Civil society in urban sanitation and solid waste management: The role of NGOs and $\mathrm{CBO}$ s in metropolises of East Africa.

Whitehead, J.C., 2006. Improving willingness to pay estimates for quality improvements through joint estimation with quality perceptions. Southern Econ. J. 73(1): 100-111. https://doi.org/10.2307/20111876

Yar, P., M.A.K. Atta-ur-Rahman and S. Samiullah. 2016. Spatio-temporal analysis of urban expansion on farmland and its impact on the agricultural land use of Mardan city, Pakistan. Proc. Pak. Acad. Sci. B. Life Environ. Sci. 53(1): 35-46.

Ye, L., X. Zhao, E. Bao, J. Li, Z. Zou and K. Cao. 2020. Bio-organic fertilizer with reduced rates of chemical fertilization improves soil fertility and enhances tomato yield and quality. Sci. Rep. 10(1): 1-11. https://doi.org/10.1038/ s41598-019-56954-2

Zezza, A. and L. Tasciotti. 2010. Urban agriculture, poverty, and food security: Empirical evidence from a sample of developing countries. Food Policy. 35(4): 265-273. https://doi. org/10.1016/j.foodpol.2010.04.007 